\title{
Socio-Cultural Conservation Strategies and Sustainability of Community Based Tourism Projects in Kenya: A Case of Maasai Mara Conservancies
}

\author{
Winnie Chebet Tubey ${ }^{1}$, Dorothy Ndunge Kyalo ${ }^{1} \&$ Angeline Mulwa ${ }^{1}$ \\ ${ }^{1}$ School of Open, Distance and Learning, University of Nairobi, Kenya \\ Correspondence: Winnie Chebet Tubey, School of Open, Distance and Learning, University of Nairobi, Kenya. \\ E-mail: wtubey@gmail.com
}

Received: October 12, 2019

Accepted: November 2, 2019

Online Published: November 28, 2019

doi:10.5539/jsd.v12n6p90

URL: https://doi.org/10.5539/jsd.v12n6p90

\begin{abstract}
The purpose of this study was to determine how social cultural conservation strategies influence the sustainability of community based tourism projects in Kenya. The objective of the study was to assess the extent to which social-cultural conservation strategies influence sustainability of community based tourism projects in Kenya. The study used descriptive survey research design and adopt a mixed methods approach anchored on pragmatism as its philosophical underpinning. The study was conducted in two conservancies in Maasai Mara; Naboisho conservancy and Olare Motorongi conservancy. The study made use of questionnaires, interviews, participant observation as well as document analysis to collect data. Qualitative data was analyzed using content analysis while quantitative data used multiple regression analysis to test the nature and strength of the relationship between variables based on observed data and to predict the value of the dependent variable based on the value of the independent variable. With $\left.r=0.891, \mathrm{r}^{2}=0.794, \mathrm{~F}(1,204)=787.02, \mathrm{p}=0.001<0.05\right]$ it was concluded that social cultural conservation strategies had a significant influence on the sustainability of community based tourism projects. The study recommends that since the culture of the Maasai community has been a tourist attraction, the older members of the community should teach and ingrain the cultural values of their community to their children. When this is done properly, there will be less danger of the younger members adopting other cultures at the expense of their rich culture.
\end{abstract}

Keywords: social-cultural conservation strategy, sustainability, community based tourism projects, protected areas

\section{Introduction}

The history of conservation can be traced back to the establishment of National parks in the USA in the late $19^{\text {th }}$ Century. This form of conservation which embodied the creation of Protected Areas (PAs) later became popular spreading to other continents including Africa (Adams, 2007). Through colonialism, protectionism conservation rapidly moved to Africa and other continents. Adams (2004) highlights the need for advancing colonial interests, promoting elite enjoyment of wildlife as well as controlling the use of natural resources by local people which was seen as unsustainable by colonialists. The protectionism campaigns viewed local practices such as traditional hunting practices as 'poaching' while plant harvesting and food gathering was termed as 'encroachment' (Mugisha 2002). Excluding the locals from decision making, the colonial governments went as far as describing their traditions, norms and rules as unscientific, illogical and superstitious thus requiring an overhaul, (Mahonge 2010). Introduction of various state institutions aimed at advancing the protectionism agenda seemed to further aggravate the situation as the local population became more resentful of the protected areas (Adams, 2004).

Nthiga (2014) notes that the agenda of sustainable development which advocates a connection between conservation and development discourse has been responsible for influencing the adoption of conservation enterprises. This is the case which since it is believed to enhance community livelihoods hence providing the required conservation incentives. Additionally, sustainable development advocates that the interventions adopted should cover three main areas: people, planet and profits, which is the main objective of the partnerships in community based tourism projects. A major critical challenge is the sustainability of the projects even after the 
departure of the donors, at the same time the beneficiaries get dividends appreciating their contribution and project possession. Williams (2003) argues that the measure of sustainability is the ability of any community in coping with changes and adapting to novel circumstances. This means that a project which is sustainable in the present may not be sustainable tomorrow.

Tourism is a development based industry which makes human interactions and service provisions very critical. The overall impact is felt to both the generating and hosting destinations. Tourism is to a large extent based on creating trust and faith among the communities involved (Shambhu and Gewali, 2014). As a result of tourism, various changes have been witnessed in various communities with people having different religious affiliations and values meeting. Tourism is credited with the advancement of education and tolerance of other people's cultures. Consequently, these interactions and consciousness have enabled people to be more tolerant of a locality's traditions and the revival of diminishing traditions that have been lost sight of with time. As a result of this working relationship and faith, people in the host community have bonded with each other as they offer services to their guests. The connectivity that has arisen from traveling from one place to the other has enhanced universal respect of all individuals and assisted in the preservation of arts and cultures. The tourists have a keen interest in the purchasing of goods as the people buy souvenirs. Tourism must have control in a manner that sustainability of the destinations is governed through the ethics of preservation of local values as well as those of hosting destinations (Ellis, 2004).

According to Singh (2008), CBT projects have the capacity of promoting the conservation of natural and cultural resources, local community development, empowering marginalized groups and attaining social inclusion in addition to the provision of employment prospects in the rural places. It is a common occurrence to get CBT projects for instance cultural villages, conservancies and eco-lodges established in community land, with many wildlife species without the protected areas. The major objectives of such projects is revenue generation in addition to provision of conservation incentives (Butcher 2011; Sumba et al. 2007; Kieti et al. 2013; Kiss 2004; Saarinen 2010).

\subsection{Statement of the Problem}

In the national tourism strategy (2013-2018) Kenya anticipates to increase tourism revenue as well as provide diverse opportunities to the local communities. The core values indicated in the strategy include: Good governance, rule of law and dignity; Inclusiveness and equity; Customer focus, responsiveness and dynamism as well as Sustainability (Government of Kenya (GoK), 2012). However, indications show that this may not significantly cascade down to indigenous communities as envisioned from this initiative.

For community conservation to be fully realized, protection of biodiversity, land use planning, mitigation of community-wildlife conflict, empowerment of the local community as well as use of traditional knowledge is a prerequisite. Reputed for its pristine wilderness and abundance of wildlife, the Maasai Mara ecosystem is threatened by the loss of wildlife grazing and dispersal areas due to agricultural practices and increased human settlement. The land tenure changes in the Mara from group ranches to private ownership has seen a significant rise in human population in wildlife dispersal areas. This is attributed to changes in the lifestyles of the Maa community from nomadic pastoralism to a more sedentary way of life, leading to large scale mechanized cultivation of land, intensification of agriculture and increased livestock production. These changes have drastically reduced the available land and resources around the PAs, creating a breeding ground for human wildlife conflict. With $65-75 \%$ of wildlife in Kenya existing in dispersal areas, the risk of competition for resources with local communities becomes greater. These changes are reflected in a study by Ogutu et al (2016) which reports extreme declines of $68 \%$ in wildlife numbers and contemporaneous increase in livestock in the Kenya rangelands from 1977 to 2016.

Furthermore, there is a pressing need to conserve the social and cultural heritage of the local community. On one hand, the Maasai are forced to use their lands in ways compatible with wildlife, yet they are not reimbursed for foregoing potential income from alternative land uses. For an average local individual, wildlife tourism does not provide an equally profitable use of their land compared to livestock or agricultural production. Moreover, other wildlife induced losses are almost never adequately addressed. In MMNR, the communities along the reserve boundaries are often are the first to pay the price for wildlife in PAs through the destruction of their crops, property, and injury or death of humans caused by roaming wild animals. In addition, roaming wildlife can transmit highly contagious diseases that can jeopardize successful livestock breeding for the Maasai. To make matters worse, the Maasai communities receive very little, if any, economic benefit from the lucrative wildlife-based tourism industry. Maasai Mara National Reserve (MMNR) is located in Narok County, where, majority of the revenue generated is captured by tourism operators and the local district councils. It is estimated 
that only $2-5 \%$ of Kenya's total tourism receipts trickle down to community households while the bulk is appropriated by local political elites (Kabiri, 2010). Other studies estimate that the amount distributed to individual land users and landowners as little as only $1 \%$ percent. As a result, communities in Masailand simply receive no economic incentives to conserve biodiversity (Akama, 2011).

Thus, this study sought to build on these discussions by examining the relationship between social cultural conservation strategies and the sustainability of community based tourism projects in Kenya. Naboisho and Olare Motorongi conservancies in Maasai Mara were selected as target areas for the study.

\subsection{Objective of the Study}

The objective of this study was to assess the extent to which social-cultural conservation strategy influence sustainability of community based tourism projects in Kenya. To achieve the objective of this study, the following hypothesis concerning the influence of social-cultural conservation strategy on the sustainability of community based tourism projects in Kenya was tested.

$\mathbf{H}_{1}$ : Social-cultural conservation strategy significantly influences sustainability of community based tourism projects in Kenya.

\section{Literature Review}

\subsection{Social-Cultural Conservation Strategy and Sustainability of Community Based Tourism Projects}

Without any doubt, tourism has a prominent effect on both the physical and cultural landscape converting these areas for tourism activities. The impacts whether they are economical, ecological or socio-cultural have elicited concerns on their future sustainability in regard to them being considered community development tools. The effects affect both the way of life of the local community and the support which they can offer to these tourism development ventures (Gursoy et al., 2002; Zhuang et al., 2019). Since tourism is a development based industry, human interactions and service provisions are critical. The overall impact is felt to both the generating and host destinations. Tourism relies heavily on creation of trust and faith among the communities involved (Shambhu and Gewali, 2014). Like other economic activities, tourism exerts a positive influence on host communities, offering developing countries a crucial opportunity to diversify their economic infrastructure, combat poverty, and pursue pro-poor policies, such as inclusive growth strategies (Dillimono and Dickinson 2016). Ramzy et al. (2013) highlights how development of tourism contributes to poverty reduction in developing island countries, such as the Comoro Islands of the Indian Ocean, through reduction in the rate of unemployment of the locals, accumulation of foreign currency reserves and the attraction of investors in tourism projects, utilizing their abundant natural resources. Since the 1970s, it has been suggested that tourism's potential as an instrument for economic development is real and that its realization is within developing countries' reach (Jafari 1974). Tourism offers a crucial opportunity for developing countries to combat poverty, diversify their economic infrastructure, and pursue pro-poor policies, such as inclusive growth strategies (Dillimono and Dickinson 2016). At the same time, the development of tourism generates social harmony and helps in the preservation of local cultures and the environment (Airey 2010; Stronza and Gordillo 2008; Dwyer et al., 2009).

In-depth interviews conducted by Saufi et al., (2014) in a study titled 'Inhibitors to host community participation in sustainable tourism development in developing countries' in Lombok, Indonesia revealed that this sector produces many advantages such as enriching residents' understanding of other cultures, strengthening their regional pride, and promoting local environmental protection. That is, the development of tourism broadens residents' knowledge about transnational tourism, foreign countries, and people, thereby instilling a sense of pride in natives associated with their heritage and culture. Zaei and Zaei (2013) divided the sociocultural impacts of tourism into seven aspects, including the improvement of local facilities and infrastructure, the availability of more events, the conservation of the local cultural heritage, a decrease in the movement of people from rural areas to urban areas, and an increase in youth exchange programmers. Zamani-Farahani and Musa (2012) also noted that tourism has not only ameliorated regional image and infrastructure construction in areas but has also been conducive to the improvement of recreational activities and quality of life among natives. Mbaiwa (2011), who examined the sociocultural impacts of tourism development in the Okavango Delta, Botswana, found that in addition to positive impacts, tourism development had negative sociocultural effects on local communities, posing a threat to the quality of life of locals. These impacts include racial discrimination, enclave tourism, the resettlement of traditional communities, the breakdown of the conventional family structure and relations, and an upsurge in crime and prostitution. Additionally, the young generations have adopted the Western Safari style of dressing and use 'vulgar' language that is traditionally unaccepted. 
Ramchander (2003) stated that older respondents in South Africa voiced their concern that traditional African culture was being commercialized. The inequality of different dweller groups' income can lead to contradictions among a community and antipathy between the locals and tourists. Canalejo, et al. (2016) reported that residents were doubtful about official support for future tourism development on the African island of São Vicente, Cape Verde, as they were discontent with the negative effects of tourism (crime, shortages of goods and services, and an absence of shopping spaces and establishments). For backpacker tourism on the Yasawa Islands in Fiji, a South Pacific island nation, Sroypetch (2016) reported that backpackers brought both active and passive changes to the sociocultural sphere. On the positive side, the hosts agreed that backpacker tourism helps revitalize local cultural practices. However, backpackers also brought negative changes in residents' dietary culture, drinking rituals, dress codes, religious values, and personal relations (with elders, family, and the community). Piuchan et al. (2018), who investigated the economic and sociocultural impacts of the increasing number of mainland Chinese tourists on Hong Kong residents, found that the negatively affected sociocultural aspects included culture, transportation, shopping, and dining, but also that conversely tourism had a positive effect on education and infrastructure construction.

The importance of culture and community norms is seen all aspects of interactions between community members. Traditions, rites, religion and beliefs all influence the relationships and organisation of communities. It permeates into individuals' lives from birth, marriage, death, property ownership and resource allocation. In sub-Saharan Africa and specifically the ASAL regions, cultural practices play a big role in the ownership and use of natural resources, further scaling down to defined gender roles and inequalities. Forsythe et al, (2015) in a study commissioned by the UNDP, in order to explore issues of dryland women's land rights, published a series of reports on dryland women which including land rights, governance and resilience. The reports underscore the value of land in developing countries and the power relations that exist within. In developing countries and in the drylands, particularly in sub-Saharan Africa and Asia, customary systems, including tenure, play an important role in managing the use and allocation of land and other natural resources. Customary tenure refers to rights to land and are held, not owned, by a group that is commonly of the same lineage or clan, that are allocated by a family or lineage head on behalf of the group (Bruce and Holt, 2011). Under customary systems, rights to access land and resources such as pasture, forest and water are provided through group membership, and can vary according to factors such as age, gender and marital status. These systems are largely unwritten and flexible. This results in a complex landscape where different types of rights and sources of rights interact in dynamic ways, which can be referred to as a land rights environment. In the drylands, the land rights environment takes on additional complexity as customary tenure is shaped towards facilitating the mobility of people and livestock, sharing resources and mobility, which is highly suitable to the variability in resources, geography, climate and weather, which is typical of the drylands (Forsythe et al, 2015).

Many conservation studies have been carried out that considered the community as a little longitudinal unit with mutual values and common interests. Previous studies have demonstrated that communities are key to the sustainability of tourism development (Aref, 2011). However, little attention is given to the communities, studying how they impact tourism development, the communities contributions cannot be downplayed because of their critical role. Jamal and Stronza (2009) argue that when the local communities are involved in tourism development, the gaps existing between governance and utilization of resources are closed up. In addition to the economic empowerment, local communities' participation assists in proper environmental conservation that is based on domestic and scientific information, economic and social development and the safeguarding of the culture of the people and the creation of interpretive and nature-based experiences for tourist learning and cross-cultural appreciation". Community participation in tourism development processes can support and uphold local culture, tradition, knowledge and skill, and create pride in community heritage (Lacy et al., 2002).

\section{Research Methodology}

The researcher employed a descriptive survey research design as it sought to determine the relationship between variables as well as concerned with making predictions, narrating facts and characteristics concerning a phenomena, (Kothari, 2004). A sample size of 266 respondents was drawn from a target population of 861 respondents comprising land owners, managers in the tourism camps, management committee members, conservancy managers and wardens. The researcher adopted a mixed method approach as it focused on the collection, analysis and combination of both quantitative and qualitative data. The core premise is that the application of both quantitative and qualitative methods together, gives a correct grasp of the research problems as opposed to the use of either of them, (Creswell and Clark, 2011). The descriptive statistics included; the use of central tendency (means, modes and medians), frequencies, proportions, standard deviation and variance. Inferential statistics employed the use of Pearson's Product Moment of Correlation $(r)$ to investigate the 
relationship i.e. the strength and association between variables.

Where:

$$
\gamma=\beta_{0}+\beta_{1} x_{1} x_{2}+\cdots+\beta_{n} x_{n}+\varepsilon
$$

$\mathrm{Y}=$ the Dependent Variable

$\mathrm{X}_{1} \ldots \mathrm{X}_{\mathrm{n}}=$ the Independent Variables

$\beta_{0}=$ Constant term (y-intercept)

$\beta_{1} \ldots \beta_{\mathrm{n}}=$ Beta Coefficients of the predictor variables

$\varepsilon=$ Error term

To evaluate how well the model fits the data, the Coefficient of Determination $\left(\mathrm{R}^{2}\right)$ was calculated. $\mathrm{R}^{2}$ is obtained by subtracting the residual value from 1 . When the variability of the residual values around the regression line relative to the overall variability is small, the predictions from the regression equation are good, (Bluman, 2013).

\section{Results and Discussion}

\subsection{Social-Cultural Conservation Strategy}

The researcher sought to measure the extent to which preservation and promotion of culture and heritage, quality and diversification of product offer, entrepreneurship opportunities for locals and the social inclusion of minority groups as aspects of social cultural conservation strategy contributed to sustainability of community based tourism projects. In achieving this 10 indicators were measured on a 5 point Likert scale. The extent to which the social cultural conservation strategy as measured by the indicators is presented in Table 1

Table 1. Social-cultural conservation strategy

\begin{tabular}{|c|c|c|c|c|c|c|c|c|}
\hline \multirow[t]{2}{*}{ Description } & \multicolumn{5}{|c|}{ Frequency and Percentage } & \multirow[t]{2}{*}{ n } & \multirow[t]{2}{*}{ Mean } & \multirow[t]{2}{*}{ SD } \\
\hline & SD & $\mathbf{D}$ & $\mathbf{N}$ & $\mathbf{A}$ & SA & & & \\
\hline \multicolumn{9}{|l|}{ Preservation and Promotion of Culture and Heritage } \\
\hline $\begin{array}{l}\text { Community members are proud of to display and market their } \\
\text { culture }\end{array}$ & $0 ; 0 \%$ & $13 ; 6.3 \%$ & $20 ; 9.7 \%$ & $45 ; 21.8 \%$ & $128 ; 62.1 \%$ & 206 & 4.40 & 0.904 \\
\hline $\begin{array}{l}\text { Visitors/tourists, respect and appreciate our cultural values and } \\
\text { norms }\end{array}$ & $0 ; 0 \%$ & $32 ; 15.5 \%$ & $19 ; 9.2 \%$ & $146 ; 70.9 \%$ & $9 ; 4.4 \%$ & 206 & 3.64 & 0.795 \\
\hline $\begin{array}{l}\text { Use of new technology, social media and other e-marketing } \\
\text { opportunities market of local culture and heritage }\end{array}$ & $0 ; 0 \%$ & $6 ; 2.9 \%$ & $20 ; 9.7 \%$ & $163 ; 79.1 \%$ & $17 ; 8.3 \%$ & 206 & 3.93 & 0.541 \\
\hline \multicolumn{9}{|l|}{ Quality and Diversification of Product Offer } \\
\hline $\begin{array}{l}\text { Community members are encouraged to be innovative to } \\
\text { create new products }\end{array}$ & $0 ; 0 \%$ & $9 ; 4.4 \%$ & $7 ; 3.4 \%$ & $157 ; 76.2 \%$ & $33 ; 16 \%$ & 206 & 4.04 & 0.608 \\
\hline $\begin{array}{l}\text { Steps have been taken to identify product gaps and increase } \\
\text { diversification }\end{array}$ & $0 ; 0 \%$ & $11 ; 5.3 \%$ & $7 ; 3.4 \%$ & $147 ; 71.4 \%$ & $41 ; 19.9 \%$ & 206 & 4.06 & 0.667 \\
\hline $\begin{array}{l}\text { There is an established product offer related to culture and } \\
\text { heritage }\end{array}$ & $0 ; 0 \%$ & $22 ; 10.7 \%$ & $11 ; 5.3 \%$ & $51 ; 24.8 \%$ & $122 ; 59.2 \%$ & 206 & 4.33 & 0.986 \\
\hline $\begin{array}{l}\text { There is improvement in the quality of cultural products and } \\
\text { services offered to tourists }\end{array}$ & $0 ; 0 \%$ & $39 ; 18.9 \%$ & $8 ; 3.9 \%$ & $124 ; 60.2 \%$ & $35 ; 17 \%$ & 206 & 3.75 & 0.953 \\
\hline \multicolumn{9}{|l|}{ Entrepreneurship Opportunities for Locals } \\
\hline $\begin{array}{l}\text { Community members are able to get income from cultural } \\
\text { practices }\end{array}$ & $0 ; 0 \%$ & $15 ; 7.3 \%$ & $8 ; 3.9 \%$ & $171 ; 83 \%$ & $12 ; 5.8 \%$ & 206 & 3.87 & 0.612 \\
\hline $\begin{array}{l}\text { Actions been taken to promote and support local investment in } \\
\text { tourism }\end{array}$ & $0 ; 0 \%$ & $23 ; 11.2 \%$ & $11 ; 5.3 \%$ & $161 ; 78.2 \%$ & $11 ; 5.3 \%$ & 206 & 3.78 & 0.711 \\
\hline Community members are able to start and own businesses & $7 ; 3.4 \%$ & $53 ; 25.7 \%$ & $10 ; 4.9 \%$ & $124 ; 60.2 \%$ & $12 ; 5.8 \%$ & 206 & 3.39 & 1.039 \\
\hline
\end{tabular}




\begin{tabular}{|c|c|c|c|c|c|c|c|c|}
\hline \multicolumn{9}{|l|}{ Social Inclusion of Minority groups } \\
\hline $\begin{array}{l}\text { Young people are involved in conservation, entrepreneurship } \\
\text { and tourism }\end{array}$ & $0 ; 0 \%$ & $37 ; 18 \%$ & $11 ; 5.3 \%$ & $115 ; 55.8 \%$ & $43 ; 20.9 \%$ & 206 & 3.80 & 0.971 \\
\hline $\begin{array}{l}\text { Women are represented in the conservancy management } \\
\text { committee }\end{array}$ & $0 ; 0 \%$ & $31 ; 15 \%$ & $9 ; 4.4 \%$ & $140 ; 68 \%$ & $26 ; 12.6 \%$ & 206 & 3.78 & 0.853 \\
\hline $\begin{array}{l}\text { People with disabilities are involved in tourism and } \\
\text { conservation activities }\end{array}$ & $0 ; 0 \%$ & $123 ; 59.7 \%$ & $21 ; 10.2 \%$ & $50 ; 24.3 \%$ & $12 ; 5.8 \%$ & 206 & 2.76 & 1.011 \\
\hline Composite Mean & & & & & & 206 & 3.81 & 0.819 \\
\hline
\end{tabular}

The responses in Table 1 revealed that community based tourism projects were generally perceived to be sustainable measured on a 5-point Likert scale. The researcher sought to obtain information on preservation and promotion of culture and heritage as an aspect of social cultural conservation strategy. The examination of the frequencies showed that a majority of the respondents, agreed that community members were proud of displaying and marketing their culture with $45(21.8 \%)$ of the respondents and $128(62.1 \%)$ of the respondents indicating that they agreed and strongly agreed with the statement respectively. The mean of this item was 4.40 $(\mathrm{SD}=0.904)$ compared to the composite mean of 3.81 implying that the respondents agreed to a greater extent that community members were proud of displaying and marketing their culture.

The researcher further sought to investigate whether there was an established product offer related to culture and heritage where 173 respondents were in agreement; $(51 ; 24.8 \%)$ agreed and strongly agreed $(122 ; 59.2 \%)$ representing $84 \%$ of the respondents. This item had a mean score of $4.33(\mathrm{SD}=0.986)$ compared to the composite mean of 3.81 implying that the respondents agreed to a greater extent that community members were proud of displaying and marketing their culture.

The study examined whether the use of new technology, social media and other e-marketing opportunities had been employed in the marketing of local culture and heritage. Majority of the respondents, $180(87.4 \%)$ responded in affirmation, with $163(79.1 \%)$ agreeing and $17(8.3 \%)$ strongly agreeing. This item had a mean score of $3.93(\mathrm{SD}=0.541)$ compared to the composite mean of 3.81 implying that the respondents agreed to a greater extent that the use of new technology, social media and other e-marketing opportunities had been employed in the marketing of local culture and heritage.

The respondents were asked to give their opinion as to whether visitors/tourists, respected and appreciated their cultural values and norms. Majority of the respondents, 155 (75.3\%) affirmed that visitors/tourists, respected and appreciated their cultural values and norms, with 146 (70.9\%) agreeing and 9 (4.4\%) strongly agreeing. However, some of the respondents, $32(15.5 \%)$ were of the contrary opinion that visitors/tourists, respected and appreciated their cultural values and norms and a few of the respondents, $19(9.2 \%)$ indicating a neutral opinion on this item. The item had a mean score of $3.64(\mathrm{SD}=0.795)$ compared to the composite mean of 3.81 implying that the respondents agreed to a lesser extent that visitors/tourists, respected and appreciated their cultural values and norms.

The researcher sought to obtain information on quality and diversification offer as an aspect of social cultural conservation strategy. The respondents were asked to give their opinion as to whether steps had been taken to identify product gaps and increase diversification, majority of the respondents, 188, responded in affirmation, with 147 (71.4\%) agreeing and 41 (19.9\%) strongly agreeing. with the item having a mean score of 4.06 (SD = $0.667)$. The item had a mean score of $4.06(\mathrm{SD}=0.667)$ compared to the composite mean of 3.81 implying that the respondents agreed to a greater extent that steps had been taken to identify product gaps and increase diversification.

As to whether community members were encouraged to be innovative to create new products, majority of the respondents, 190, responded in affirmation, with 157 (76.2\%) agreeing and $33(16.0 \%)$ strongly agreeing. The item had a mean score of $4.04(\mathrm{SD}=0.608)$ compared to the composite mean of 3.81 implying that the respondents agreed to a greater extent that community members were encouraged to be innovative to create new products.

The researcher also sought to find out whether there were entrepreneurship opportunities available for the locals. The respondents were asked to give their opinion as to whether community members were able to get income 
from cultural practices. Majority of the respondents, 183 (88.8\%) were in agreement, with $171(83.0 \%)$ agreeing and $12(5.8 \%)$ strongly agreeing. with the item having a mean score of $3.87(\mathrm{SD}=0.612)$. The item had a mean score of $3.87(\mathrm{SD}=0.612)$ compared to the composite mean of 3.81 implying that the respondents agreed to a greater extent that community members were able to get income from cultural practices.

As to whether actions had been taken to promote and support local investment in tourism, majority of the respondents $172(83.5 \%)$ were in agreement, with 161 (78.2\%) agreeing and $11(5.3 \%)$ strongly agreeing. Majority of the respondents, $136(66 \%)$ affirmed that community members are able to start and own businesses, with $124(60.2 \%)$ agreeing and $12(5.8 \%)$ strongly agreeing. However, almost a quarter of the respondents, 53 (25.7\%) were of the contrary opinion that community members were able to start and own businesses and a few of the respondents, $10(4.9 \%)$ indicating a neutral opinion on this item. The item had a mean score of $3.39(\mathrm{SD}=$ 1.039) compared to the composite mean of 3.81. The findings therefore, indicate that entrepreneurship opportunities had been made available to most members of the community but not all have benefited.

The researcher sought to establish whether there was social inclusion of minority groups in conservation activities. From the responses of majority of the respondents, $158(76.7 \%)$ affirmed that young people were involved in conservation, entrepreneurship and tourism activities, with $115(55.8 \%)$ agreeing and $43(20.9 \%)$ strongly agreeing. The item had a mean score of $3.80(\mathrm{SD}=0.971)$ compared to the composite mean of 3.81 implying that the respondents agreed to a slight extent that that young people were involved in conservation, entrepreneurship and tourism activities.

It was also established that women were represented in the conservancy management committees, $166(80.6 \%)$ responded in affirmation, with $140(68 \%)$ agreeing and $26(12.6 \%)$ strongly agreeing. The item had a mean score of $3.78(\mathrm{SD}=0.853)$ compared to the composite mean of 3.81 implying that the respondents agreed to a lesser extent that women were represented in the conservancy management committees.

However, majority of the respondents, $123(59.7 \%)$ disagreed that people with disabilities were involved in tourism and conservation activities and a few of the respondents, $21(10.2 \%)$ indicating a neutral opinion on this item. This item had a mean score of $2.76(\mathrm{SD}=1.011)$ compared to the composite mean of 3.81 . The findings of the study therefore, indicate that as much as more youth and women were involved in conservancy and tourism activities, people with disabilities were a bit disadvantaged, a group which should be considered to achieve better social inclusion of minority groups.

The composite mean of social cultural conservation strategy was 3.81 with an SD of 0.819 . This implies that there were varied opinions with majority of responses (68\%) lying between 2.99 and 4.63 of the mean. Thus, more effort is required to strengthen social cultural conservation initiatives in order to enhance its significance to the sustainability of community based tourism projects.

4.2 Relationship between Social-Cultural Conservation Strategy and Sustainability of Community Based Tourism Projects

The relationship between social cultural conservation strategy and sustainability of community based tourism projects using Pearson Correlation Coefficient. The Pearson Correlation results are presented in Table 2

Table 2. Social-cultural conservation strategy pearson correlation

\begin{tabular}{llr}
\hline \multicolumn{3}{l}{ Sustainability of Community Based Tourism Projects } \\
\hline Social Cultural Conservation Strategy & Pearson Correlation & $0.891 * *$ \\
& Sig. (2-tailed) & 0.000 \\
& $\mathrm{~N}$ & 206 \\
\hline$* *$ Correlation is significant at the 0.01 level (2-tailed). \\
\hline
\end{tabular}

Table 2 indicates the Pearson Correlation between social cultural conservation strategy and sustainability of community based tourism projects. The results revealed a strong positive linear correlation between social cultural conservation strategy and sustainability of community based tourism projects $(r=0.891, p<0.01)$. This implies that effective social cultural conservation strategies positively contribute to the sustainability of community based tourism projects. 


\subsection{Hypothesis Testing}

The findings of quantitative data were further analyzed using linear regression analysis to test the hypothesis of social-cultural conservation strategy.

Hypothesis: Socio-cultural conservation strategy has no significant influence on the sustainability of community based tourism projects in Kenya

The hypothesis was tested using the following model

$\gamma_{1}=\beta_{0}+\beta_{2} \mathrm{x}_{2}+\varepsilon$

Where:

$\mathrm{Y}_{1}=$ Sustainability of Community Based Tourism Projects

$\mathrm{X}_{2}=$ Social Cultural conservation strategies

$\beta_{0}=$ Constant term (y-intercept)

$\beta_{2} \ldots \beta_{\mathrm{n}}=$ Beta Coefficients of the predictor variables

$\varepsilon=$ Error term

Table 3. Model summary for social cultural conservation strategy

\begin{tabular}{|c|c|c|c|c|c|c|c|c|c|}
\hline \multirow{2}{*}{\multicolumn{2}{|c|}{$\mathrm{R}$}} & \multirow[t]{2}{*}{ R Square } & \multirow[t]{2}{*}{ Adjusted R Square } & \multirow[t]{2}{*}{ Std. Error of the Estimate } & \multicolumn{5}{|l|}{ Change Statistics } \\
\hline & & & & & R Square Change & F Change & df1 & df 2 & Sig. F Change \\
\hline 1 & $0.891 \mathrm{a}$ & 0.794 & 0.793 & 0.21052 & 0.794 & 787.02 & 1 & 204 & 0.000 \\
\hline
\end{tabular}

a. Predictors: (Constant), Social Cultural Conservation Strategy

The study results shown in Table 3 provides an explanation on the extent to which the predictor variable accounts for the overall variability of the model. The R Square is given as 0.794 indicating that socio-cultural conservation strategy contributed to the sustainability of community based tourism projects by $79.4 \%$ and other factors which were not considered in this model accounted for $20.6 \%$. The Adjusted R Square gives an indication that if the whole population was taken into account in this study as opposed to choosing a sample, then the response would be (1-0.793) $20.7 \%$ less variance. Hence, the researcher deduced that socio-cultural conservation strategy has a significant influence on the sustainability of community based tourism projects.

Table 4. Coefficients of social cultural conservation strategy

\begin{tabular}{lllllll}
\hline \multirow{2}{*}{ Model } & & \multicolumn{2}{l}{ Unstandardized Coefficients } & Standardized Coefficients & $\mathrm{t}$ & Sig. \\
& & $\mathrm{B}$ & Std. Error & Beta & & \\
\hline \multirow{2}{*}{1} & (Constant) & 0.079 & 0.088 & & 0.903 & 0.368 \\
& Social Cultural Conservation Strategy & 0.888 & 0.032 & 0.891 & 28.054 & 0.000
\end{tabular}

a. Dependent Variable: Sustainability of Community Based Tourism Projects

The results in Table 4 generated a beta value of 0.888 indicates that a unit increase of Socio-cultural conservation strategies contributed to $88.8 \%$ increase in the sustainability of community based tourism projects. Overall the model was statistically significant at $\mathrm{P}<0.05$. The $\mathrm{F}$ ratio was significant, $\mathrm{F}(1,204)=787.02, \mathrm{P}<0.05$. This indicates that there was a statistically significant influence of socio-cultural conservation strategies on sustainability of community based tourism projects. Thus the regression model would be:

Sustainability $=0.079+0.888$ (socio cultural conservation strategy) $+\varepsilon ; \mathrm{t}=28.05 ; \mathrm{P}<0.05$

Thus, the null hypothesis of the study was rejected and the alternative hypothesis accepted. In view of this socio-cultural conservation strategy has a significant influence on the sustainability of community based tourism projects at $\mathrm{P}<0.05$.

The researcher further sought to validate the quantitative information by conducting interviews with key informants and analysing this data. The study sought to determine the opinion of respondents on how 
sociocultural conservation strategies influenced sustainability of community based tourism in Kenya. Respondents were in agreement that preservation of culture and heritage was a big component of socio-cultural conservation, reflecting that the community was proud of their culture and willing to display and showcase it. A key respondent was captured saying:

'The Maa people have had a long and proud heritage that is sacred and we guard it jealously. We value our way of life and people come all over the world to see how we live, how we dress and even what we eat. Some want to settle here, marry and have children ... it means they must have seen something good.'

However, there were concerns that visitors and tourists had little appreciation to their cultural values and norms, only partaking of it as a commodity. These sentiments were shared:

'We are afraid that our young people will lose their heritage by emulating the visitors. You can see it in their manner of dressing and behaviour. Some shun our traditions terming them as old fashioned.'

These comments reveal that the community does appreciate the value of their culture and would like to promote culture as a tourism product. They are however wary of the long term effects that external influences would have on their traditions and way of life. It would be impossible to separate the tourism product in Maasai Mara from the culture and traditions of the Maasai people. The findings in this study concur with Lussetyowati (2015) in an explorative study of cultural tourism in Indonesia using in depth interviews to collect data, highlights that cultural heritage tourism has a number of objectives that must be met within the context of sustainable development, such as conservation of cultural resources, accurate interpretation of resources, authentic visitor experience, and stimulation for revenues of cultural resources.

Respondents were further asked about their opinion regarding quality and diversity of the tourism product to which they agreed that there was concerted effort to encourage innovative ideas and improve cultural products and services. Giving an example of homestays as a product diversification measure, a respondent stated:

'We have tourists coming all the way from Europe to come and live in our homes, cook and perform daily activities as part of the cultural tourism experience. Some are given space within a homestead to build their own 'manyattas' and others reside with a local family for a period of time'

This sentiment reveals the extent to which the community is willing to provide an authentic visitor experience and package their products in a unique manner. Moreover, strides are being made to promote and encourage local people to start and own businesses. Small and medium sized enterprises such as curio shops, tour companies and motels were cited some of the investments that the community participated in. It was pointed out however that community members had a hard time accessing credit and this made it difficult to effectively take advantage of entrepreneurship opportunities. They further expressed their displeasure that these opportunities were taken up by foreigners or people from outside the community. One respondent quipped:

'financial institutions do not want to give us loan facilities so that we can invest in the community, that is why outsiders come and take over everything...it is unfair that we are the owners of the resources yet we can't fully enjoy the benefits.'

A conservancy manager expounded that they encourage their members to seek alternative methods of funding:

'As a conservancy, we tell our members to form groups popularly known as 'Chamas', where they can save and borrow as a group as well as join SACCOs. This helps them access a little financial credit that can be used to for investment'

It emerged that the conceptualization of entrepreneurship in the conservation is still through traditional thinking where individuals set up private initiatives with the hope that it can sustain their livelihoods with little regard to social impacts. This school of thought diverges from the findings by Mayaka et al., (2017), whose qualitative study of CBTs in Kenya, suggest a bottom-up approach in which control and benefits, both social and economic, predominantly accrue to the neediest because the process is a response by the needy to issues identified by the needy. This is also highlighted in Thomas (2013) in his book, 'small firms in tourism', and taking different perspectives of how small businesses are conducted in tourism. Suggestions are made that entrepreneurs in communities should aim at contributing to social benefits at the fore as opposed to financial gain solely. The study findings are however supported by previous studies that entrepreneurship for CBT projects is a means for emancipation (Rindova et al 2009) and a vehicle of enhancing community identity and sustainability.

On product quality and diversification, respondents pointed out that as much as they were engaging in tourism, they were doing do to diversify their incomes, however, their passion as Maa people was in pastoralism. In their research on mainly agro-pastoral households in arid to semi-arid regions in Kenya, Barret et al., (2005) suggest 
that between 2002 and 2004, more than $60 \%$ of the investigated Kenyan households earned (additional) money from off-farm agricultural labour and that $29 \%$ the of the analysed rural households' income was constituted from non-farm income. These findings further converge with those of Radeny et al (2007) who investigated an area close to the metropolitan area of Nairobi and suggest that in this case up to $85 \%$ of the households have access to income sources unrelated to livestock and crops. Despite the mentioned limitations, these two examples might substantiate a commonly suggested phenomenon that rural or pastoral households tend to increasingly diversify their livelihoods.

Finally, the researcher asked respondents for their views on social inclusion of minority groups. There was general consensus that women young people and people living with disabilities were more involved in conservation and tourism activities, however, their participation was limited. An in-depth review of the discussions revealed that in the formative years of the formation of the conservancies, very few women attended conservancy meetings. Those that did attend were conservancy members who had inherited land from their husbands. Although wives of members were reportedly invited to attend meetings, very few attended. This is consistent with Bedelian (2014) who reported that in the community interviews she conducted, no woman reported having attended a conservancy meeting as they knew very little about conservancies since they were not members and did not attend conservancy meetings. Rather, women got information about the conservancy from their husbands who would attend meetings.

Women are often excluded from decision making, negotiation and information process that governs the clans and leadership system that is the interface with the conservancies. Legal provisions in conservancy documents also discriminate against women. Widespread resistance to change for fear of losing power or changing the status quo makes it difficult for women to access, influence or benefit from these structures. Community-level participation similarly can often leave women's voices and concerns unacknowledged. Even when women attend meetings or events, women may not sit with male elders, speak before male elders, and they may not be or feel free to voice their opinions and needs may not be taken seriously. The Wildlife Conservation and Management Act of 2013 (WCMA) is supportive and gives formal recognition to the collective voice of conservancies at the landscape national levels. Yet significant gender disparities still exist in the conservancies' leadership (boards, committees and management) and within the staff (permanent and casual). For instance, at the national level, KWCA (14\%) of the board membership are women while (44\%) are in the secretariat. This low threshold limits women's visibility, influence and power in decision-making processes at all levels in the conservancies. KWCA in a Gender Strategy (2019), further reports that, less than 5\% of landholding within conservancies are held by women; a marginal ownership indicating that tenure remains strongly a male domain in most pastoral communities, women and the youth are often unrepresented or entirely excluded. Lack of access to land deprives them of an important economic tool for improving livelihoods. Currently, less than $10 \%$ of conservancy committee members are women. Only two women have been elected to chair two conservancies within the Northern Rangeland Trust. This is because traditionally, women do not own land and further perpetuated by the gender insensitive land laws under the repealed Group Land (Representatives) Act and Trust Lands Act. This limits women participation in decision making on land, natural resource management and accessing benefits.

Realising that women and young people were largely left out and uninformed about conservancy activities, the conservancy management at OMC and Naboisho Conservancies begun a community outreach programme with women in 2010. Female outreach officers were employed by the conservancy Trust and set up eight women's groups throughout Koyiaki. The groups would meet regularly to discuss issues related to the conservancies, environment and community development. The discussions would centre around topics like alternative sources of energy, education, microfinance, health and family planning. Bedelian (2014) supports this in her research stating that women groups were set up in areas where there no nearby cultural manyattas where the women could sell their beads or craft and earn some income. These groups would then give them advocacy skills and knowledge on the importance of girls' education.

\section{Study Findings}

The study objective sought to assess the influence of socio-cultural conservation strategy on the sustainability of Community Based Tourism Projects in Kenya. The study found that social cultural conservation strategy had been enhanced by preservation and promotion of culture and heritage since the community members were proud of their culture and were willing to display and showcase it. Furthermore, social cultural conservation strategy was enhanced by quality and diversification of products offered since there were concerted efforts to encourage innovative ideas and improvement of cultural products and services for instance the homestays where tourists would stay with the locals in their homes. Concerning social inclusion of minority groups enhancing social cultural conservation strategies, it was established that women, young people and people living with disabilities 
were more involved in conservation and tourism activities. However, this was not the case in the formative years of the formation of the conservancies, because very few women attended conservancy meetings. Those that did attend were conservancy members who had inherited land from their husbands, with a small number of their spouses attending even when invited. The community members opined that it was hard for them to access credit facilities which made it difficult to effectively take advantage of entrepreneurship opportunities. They further expressed their displeasure that these opportunities were taken up by foreigners or people from outside the community.

The study also established that social-cultural conservation strategy had a significant influence on sustainability of community Based Tourism Projects at $5 \%$ confidence level $(\mathrm{p}<0.001)$. The regression results implied that a unit increase of social-cultural conservation strategies contributed to 0.888 units increase in the sustainability of community based tourism projects. This implies that effective social-cultural conservation strategies contribute to the sustainability of community based tourism projects. Thus, from the regression results, the null hypothesis of the study was rejected and the alternative hypothesis accepted. In view of this socio-cultural conservation strategy has a significant influence on the sustainability of community based tourism projects at $\mathrm{P}<0.05$.

\section{Conclusions}

The objective of the study established that social cultural conservation strategy had an influence on the sustainability of community based tourism projects. The study findings revealed the existence of a strong positive linear correlation between social cultural conservation strategy and sustainability of community based tourism projects. This implies that effective social cultural conservation strategy factors (preservation and promotion of culture and heritage, quality and diversification of products offered, entrepreneurship opportunities for locals and the social inclusion for minority groups) enhanced the sustainability of community based tourism projects.

\section{Recommendations}

The study established that social cultural conservation strategy influenced the sustainability of the community based tourism projects. The preservation and the promotion of culture and heritage was shown to contribute to sustainability of the tourism projects. Some community members however, expressed fear of external influences which had made the younger generation to copy the western way of life at the expense of their culture. Since the culture of the Maasai community has been a tourist attraction, the study recommends that the older members of the community should teach and ingrain the cultural values of their community to their children. When this is done properly, there will be less danger of the younger members adopting other cultures at the expense of their rich culture.

\section{References}

Adams, W. M. (2004). Against extinction: the story of conservation. London: Earthscan

Adams, W., \& Hutton, J. (2007). People, parks and poverty: political ecology and biodiversity conservation. Conservation and Society, 5(2), 147-83.

Akama, J. S., Maingi, S., \& Camargo, B. (2011). Wildlife conservation, safari tourism and the role of tourism certification in Kenya: A postcolonial critique. Tourism Recreation Research, 36, 1-11. https://doi.org/10.1080/02508281.2011.11081673

Arnstein, S. R. (1969). A ladder of citizen participation. Journal of the American Institute of Planners, 35(4), 216-224. https://doi.org/10.1080/01944366908977225

Barrett, C. B., Bezuneh, M., Clay, D., \& Reardon, T. (2005). Heterogeneous Constraints, Incentives, and Income Diversification Strategies in Rural Africa. Quarterly Journal of International Agriculture, 44(1), 37-60. Retrieved http://dyson.cornell.edu/special_programs/AFSNRM/Parima/Papers\%20from\%20Cbb2/Papers/BBCR_May 2004

Bedelian, C. E. (2014). Conservation, tourism and pastoral livelihoods: wildlife conservancies in the Maasai Mara, Kenya (Doctoral dissertation, UCL (University College London)).

Bluman, A. G. (2013). Elementary statistics: A step by step approach: A brief version (No. 519.5 B585E.). McGraw-Hill.

Butcher, J. (2011). Can ecotourism contribute to tackling poverty? The importance of 'symbiosis'. Current Issues in Tourism, 14(3), 295-307. https://doi.org/10.1080/13683500.2011.555526 
Canalejo, A. M. C., Tabales, J. M. N., \& Cañizares, S. M. S. (2016). Local community perceptions on tourist impacts and associated development: A case study on Sal and Boa Vista Islands. Mediterranean Journal of Social Sciences, 7(1 S1), 383. https://doi.org/10.5901/mjss.2016.v7n1s1p383

Courtney, C. (2016). Sustainable Africapitalism? Grassroots perceptions of Maasai Mara conservancies and their relationship with development.

Creswell, J. W., Klassen, A. C., Plano Clark, V. L., \& Smith, K. C. (2011). Best practices for mixed methods research in the health sciences. Bethesda (Maryland): National Institutes of Health, 2013, 541-545.40(1), pp 71-80.

Dillimono, H. D., \& Dickinson, J. E. (2015). Travel, tourism, climate change, and behavioral change: travelers' perspectives from a developing country, Nigeria. Journal of Sustainable Tourism, 23(3), 437-454. https://doi.org/10.1080/09669582.2014.957212

Dwyer, L., Edwards, D., Mistilis, N., Roman, C., \& Scott, N. (2009). Destination and enterprise management for a tourism future. Tourism management, 30(1), 63-74. https://doi.org/10.1016/j.tourman.2008.04.002

Ellis, F. (2000). Rural livelihoods and diversity in developing countries. Oxford; New York, NY: Oxford University Press

Forsythe, N., Pepin, N., Bradley, R. S., Diaz, H. F., Baraër, M., Caceres, E. B., .. Miller, J. R. (2015). Elevation-dependent warming in mountain regions of the world. Nature Climate Change, 5(5), 424-430. https://doi.org/10.1038/nclimate2563

Government of Kenya; Ministry of Tourism. (2012). National tourism strategy 2013-2018.

Gursoy, D., Jurowski, C., \& Uysal, M. (2002). Resident attitudes: A structural modeling approach. Annals of tourism research, 29(1), 79-105. https://doi.org/10.1016/S0160-7383(01)00028-7

Jafari, J. (1974). The socio-economic costs of tourism to developing countries. Annals of Tourism Research, 1(7), 227-262. https://doi.org/10.1016/0160-7383(74)90018-8

Kabiri, N. 2010. The political economy of wildlife conservation and decline in Kenya. Journal of Environment \& Development, 19(4), 424-445. https://doi.org/10.1177/1070496510384463

Kellert, S. R., Mehta, J. N., Ebbin, S. A., \& Lichtenfield, L. L. (2000). Community natural resource management: promise, rhetoric, and reality community natural resource management. Soc. Nat. Resour., 13(8), 705-715. https://doi.org/10.1080/089419200750035575

Kenya Wildlife Conservancies Association, KWCA. (2019). Gender Strategy. KWCA publications, Nairobi.

Kieti, D., Manono, G., \& Momanyi, S. (2013). Community Conservation Paradigm: The Case Studies of Mwaluganje Elephant Sanctuary and ILNgwesi Community Conservancy in Kenya. Research on Humanities \& Social Sciences, 3(1).

Kiss, A. (2004). Is community-based ecotourism a good use of biodiversity conservation funds? Trends in Ecology and Evolution, 19(5), 232-237. https://doi.org/10.1016/j.tree.2004.03.010

Kothari, C. R. (2004). Research methodology: Methods and techniques. New Age International.

Lacy, T. D., Battig, M., Moore, S., \& Noakes, S. (2002). Public / Private Partnerships for Sustainable Tourism. In delivering a sustainability strategy for tourism destinations: Asia Pacific Economic Cooperation. Apec Tourism Working Group.

Lussetyowati, T. (2015). Preservation and conservation through cultural heritage tourism. Case study: Musi Riverside Palembang. Procedia-Social and Behavioral Sciences, 184, 401-406. https://doi.org/10.1016/j.sbspro.2015.05.109

Mahonge, C. P. (2010). Co-managing complex social- ecological systems in Tanzania, The case of Lake Jipe Wetland. Environmental Policy Series, Vol. 2. Wageningen Academic Publishers, Wageningen. https://doi.org/10.3920/9789086867073

Mayaka, M., Croy, G. W., \& Cox, J. W. (2017). Participation as motif in community-based tourism: a practice perspective. Journal of Sustainable Tourism. https://doi.org/10.1080/09669582.2017.1359278

Mbaiwa, J. E. (2011). Changes on traditional livelihood activities and lifestyles caused by tourism development in the Okavango Delta, Botswana. Tourism Management, 32(5), 1050-1060. https://doi.org/10.1016/j.tourman.2010.09.002 
Measham, T. G., \& Lumbasi, J. (2013). Success factors for Community Based Natural Resource Management (CBNRM): lessons from Kenya and Australia. Environmental Management, 52(3), 649-659. https://doi.org/10.1007/s00267-013-0114-9

Mugisha, A. (2002). Evaluation of community based conservation approaches: management of protected areas in Uganda. Dissertation University of Florida, Nantonga, USA.

Neubauer, F. (2014). New Opportunities and New Constraints - Understanding Changes in Land Tenure and Livelihoods among the Pastoral Maasai in Southern Kenya. Msc thesis, Wangeinigen University.

Nthiga, R. W., Mwongela, B., \& Zellmer, K. (2011). Conservation through Tourism: The Conservation Enterprise Model of the African Wildlife Foundation. In Van der Duim, V. R. Meyer, D., Saarinen, J., \& Zellmer, K. (Eds.), New Institutional Arrangements for Tourism, Conservation and Development in Sub-Saharan Africa (pp. 84-106). Delft, Eburon.

Ogutu, J. O., Piepho, H.-P., Said, M. Y., Ojwang, G. O., Njino, L. W., Kifugo, S. C., \& Wargute, P. W. (2016). Extreme wildlife declines and concurrent increase in livestock numbers in Kenya: What are the causes? PLos One, 11, e0163249. https://doi.org/10.1371/journal.pone.0163249

Piuchan, M., Chan, C. W., \& Kaale, J. (2018). Economic and socio-cultural impacts of Mainland Chinese tourists on Hong Kong residents. Kasetsart Journal of Social Sciences, 39(1), 9-14. https://doi.org/10.1016/j.kjss.2017.11.004

Radeny, M., Nkedianye, D., Kristjanson, P., \& Herrero, M. (2007). Livelihood choices and returns among pastoralists. Evidence from Southern Kenya. Nomadic Peoples, 11(2), 31-55. https://doi.org/10.3167/np.2007.110203

Saarinen, J. (2010). Local tourism awareness: community views in Katutura and King Nehale conservancy, Namibia. Development Southern Africa, 27(5), 713-724. https://doi.org/10.1080/0376835X.2010.522833

Saufi, A., O'Brien, D., \& Wilkins, H. (2014). Inhibitors to host community participation in sustainable tourism development in developing countries. Journal of Sustainable Tourism, 22(5), 801-820. https://doi.org/10.1080/09669582.2013.861468

Shambhu, K. C., \& Gewali, J. (2014). Analysing socio-economic impacts of tourism: Case of Lumbini region-Nepal.

Singh, P. K. (2008). Medical tourism. New Delhi, India: Kanishka Publishers.

Sroypetch, S. (2016). The mutual gaze: Host and guest perceptions of socio-cultural impacts of backpacker tourism: A case study of the Yasawa Islands, Fiji. Journal of Marine and Island Cultures, 5(2), 133-144. https://doi.org/10.1016/j.imic.2016.09.004

Stronza, A., \& Gordillo, J. (2008). Community views of ecotourism. Annals of tourism research, 35(2), 448-468. https://doi.org/10.1016/j.annals.2008.01.002

Sumba, D., Warinwa, F., Lenaiyasa, P., \& Muruthi, P. (2007). The Koija Starbeds ecolodge: A case study of a conservation enterprise in Kenya. African Wildlife Foundation Working Papers (October 2007). Nairobi: African Wildlife Foundation.

Thomas, R. (2013). Small firms in tourism. Routledge. https://doi.org/10.4324/9780080517285

Williams, M. (2003). Sustainable development and social sustainability. Hull, QC: Strategic research and Analysis, Department of Canadian Heritage. Reference: SRA-724.

Zaei, M. E., \& Zaei, M. E. (2013). The impacts of tourism industry on host community. European journal of tourism hospitality and research, 1(2), 12-21.

Zamani-Farahani, H., \& Musa, G. (2012). The relationship between Islamic religiosity and residents' perceptions of socio-cultural impacts of tourism in Iran: Case studies of Sare'in and Masooleh. Tourism Management, 33(4), 802-814. https://doi.org/10.1016/j.tourman.2011.09.003

\section{Copyrights}

Copyright for this article is retained by the author(s), with first publication rights granted to the journal.

This is an open-access article distributed under the terms and conditions of the Creative Commons Attribution license (http://creativecommons.org/licenses/by/4.0/). 